\title{
Synthesis, Characterization and Antimicrobial Assay of Azo Dyes derived from 4- Nitrocatechol Phenolic Moiety
}

\section{Sonali Lokhande ${ }^{1}$ and Nandakishore Thakare ${ }^{2}$}

\author{
${ }^{1}$ Research student, Department of chemistry, M. S. P. Arts, Science and K. P. T. \\ Commerce College, Manora, Dist.- Washim, Maharashtra, India \\ ${ }^{2}$ Research Guide, Department of chemistry, M. S. P. Arts, Science and K. P. T. \\ Commerce College, Manora, Dist.- Washim, Maharashtra, Ind ia
}

\begin{abstract}
Series of novel azo compounds were synthesized from di-substituted phenolic moiety i.e. 4-nitro catechol (1, 2-dihydroxy-4-nitrobenzene) and characterized by ${ }^{1} \mathrm{H}-\mathrm{NMR}$, FT-IR and mass spectroscopy. Diazonium salts were prepared by using different substituted aromatic amines viz. aniline, o-Nitro aniline, p-Toluidine, $\alpha$ Naphthylamine, m-Nitroaniline, benzedine, sulphanilic acid and anthranilic acid at low temperature. Prepared azo dyes shows significant yield and possess wide range of colours. Further the synthesized azo dyes were screened for antimicrobial activities against four pathogens by disc diffusion method to study biological activity. Physical properties are also studied. From the study result revealed that synthesized new azo dyes shows good antimicrobial act ivity.
\end{abstract}

Keywords: 1, 2-dihydroxy-4-nitrobenzene, Disc diffusion, antimicrobial activity

\section{Introduction}

Azo dyes are commercially very important and most acceptable class of organic compounds of dyes contains at least one conjugated azo group and chromophore. chromophoric moiety may be associated with two or more aromatic groups to enhance the colour (Patni, 2006). Azo compounds possess wide applications in many areas and extensively used as colorants in textile industry, dyes for detection and characterization of drugs and pharmaceuticals, in digital printing and photography (Pranab and Begum, 2018). Azo compounds played an essential role as antibacterial, antifungal, anticancer, antiviral, anti-inflammatory (Khadim M. and Obaid, 2018) and antituberculosis agents in the development of drugs in pharmaceutical industries (Thakare N, Ingole D et. al. 2017). They also exh ibit potential applications in biological reactions such as inhibition of RNA, protein synthesis and nitrogen fixation (Keshawayaa M, 2018) (Rajesh et. Al. 2017) Azo dyes received great attention due to its environmental stable nature, ease of preparation and its electrical and optical properties. They used largely in the textile industries, fiber, leather, paint and printing industries, also used in advanced technology areas like laser, liquid crystalline display, electro-optical devices and ink jet printers ( Rathod et al 2013). Azo dyes find large applications in different industries like garments, food additives, cosmetics, agriculture and ointment and as indicators in laboratories (Shelke et al 2016). Synthesis of azo compounds followed by two steps, first one was formation of diazonium salt and second was azocoupling reaction (Kate S. et. al. 2016)

Due to large applications of azo dyes in various field the present work is focused on the synthesis, characterization and antimic robial screening of azo dyes, which were easily synthesized by coupling reaction of 1,2-dihydroxy-4-nitrobenzene with eight different substituted anilines successively 


\section{Materials and method:}

\subsection{Materials:}

The chemicals used in the present study of synthetic grade. The products were characterized by $\mathrm{H}^{1}$-NMR and IR. The IR spectra recorded by Perkin Elmer spectrum FT-IR spectrophotometer, the $\mathrm{H}^{1}$-NMR spectra were recorded by Brucer Avance 400 NMR spectrometer. The biological activities of synthesized dyes were evaluated against four micro-organisms viz. Escherichia Coli, Staphylococcus Aureus, Pseudomonas Aeroginosa and Salmonella Typhi by Disc diffusion method. The crude products were recrystallized by using ethanol as solvent.

\section{General procedure for synthesis of azo dyes containing 4-nitro catechol:}

2.2 Method: Aromatic amine like o-nitroaniline (0.01 mole) was mixed with conc. $\mathrm{HCl}(2.5 \mathrm{ml})$. The resultant suspension crushed into ice and $2.5 \mathrm{ml}(4 \mathrm{~N})$ cold $\mathrm{NaNO}_{2}$ solution was added with stirring. The temperature of reaction was maintained upto $0-5^{0} \mathrm{C}$ then diazotization was carried out over 15-20 mints. The diazonium salt solution prepared above is added dropwise to the alkaline solution of Disubstituted Phenol. Stirred the reaction mixture and maintained the temperature $5-10^{\circ} \mathrm{C}$. The coloured products obtained (3a-3h) was filtered and dried and recrystallized by using ethanol.

\subsection{Reaction scheme:}

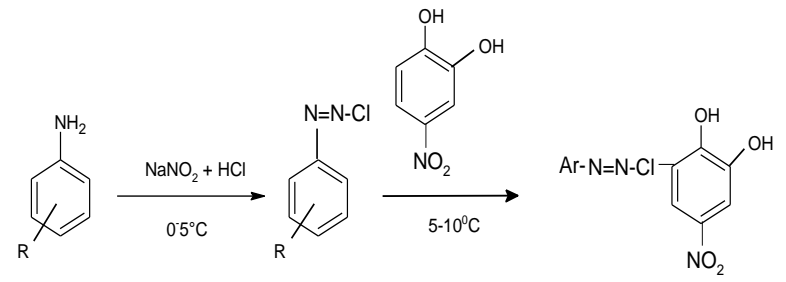

\section{Substituted aromatic amines used for} diazotization are as:<smiles>Nc1ccccc1</smiles>

a)<smiles>Nc1ccccc1[N+](=O)[O-]</smiles>

b)<smiles>Cc1ccc(N)cc1</smiles>

c)<smiles>Nc1cccc2ccccc12</smiles>

d)<smiles>Nc1ccc(C(=O)O)cc1</smiles>

g)<smiles>Nc1cccc([N+](=O)[O-])c1</smiles>

e)<smiles>Nc1ccc(-c2ccc(N)cc2)cc1</smiles>

h)

\section{Result:}

Table 1: Code of compound, molecular formulae, molecular weight, colour and yield of synthesized azo compounds deri ved from 4-nitro catechol

\begin{tabular}{|c|c|c|c|c|}
\hline Code & $\begin{array}{c}\text { Molecular } \\
\text { for mula }\end{array}$ & $\begin{array}{c}\text { Molecular } \\
\text { weight }\end{array}$ & Col our & Yield \\
\hline $3 \mathrm{a}$ & $\mathrm{C}_{12} \mathrm{H}_{9} \mathrm{~N}_{3} \mathrm{O}_{4}$ & 259 & Red & $56 \%$ \\
\hline $3 \mathrm{~b}$ & $\mathrm{C}_{12} \mathrm{H}_{6} \mathrm{~N}_{6} \mathrm{O}_{4}$ & 307 & $\begin{array}{c}\text { Orange } \\
\text { red }\end{array}$ & $73 \%$ \\
\hline $3 \mathrm{c}$ & $\mathrm{C}_{13} \mathrm{H}_{11} \mathrm{~N}_{3} \mathrm{O}_{4}$ & 274 & Orange & $79 \%$ \\
\hline $3 \mathrm{~d}$ & $\mathrm{C}_{16} \mathrm{H}_{11} \mathrm{~N}_{3} \mathrm{O}_{4}$ & 309 & White & $67 \%$ \\
\hline $3 \mathrm{e}$ & $\mathrm{C}_{12} \mathrm{H}_{8} \mathrm{~N}_{4} \mathrm{O}_{6}$ & 304 & Brown & $61 \%$ \\
\hline $3 \mathrm{f}$ & $\mathrm{C}_{18} \mathrm{H}_{14} \mathrm{~N}_{4} \mathrm{O}_{4}$ & 336 & $\begin{array}{c}\text { Brown } \\
\text { Red }\end{array}$ & $53 \%$ \\
\hline $3 \mathrm{~g}$ & $\mathrm{C}_{12} \mathrm{H}_{9} \mathrm{~N}_{3} \mathrm{O}_{7} \mathrm{~S}$ & 340 & Brown & $83 \%$ \\
\hline $3 \mathrm{~h}$ & $\mathrm{C}_{13} \mathrm{H}_{9} \mathrm{~N}_{3} \mathrm{O}_{6}$ & 303 & Black & $59 \%$ \\
\hline
\end{tabular}

\section{Compound 3a}

2-hydro xy-4-nitro (phenyl diazenyl) phenol

IR $\left(\mathbf{c m}^{-\mathbf{1}}\right)$ : 3374, 3230 (Phenolic -OH), $3057(\mathrm{C}-\mathrm{H}$ stretching of Ar) $1502(v-N=N), 1599(v \mathrm{C}=\mathrm{C}$ of $\mathrm{Ar})$, 1243( $v \mathrm{C}-\mathrm{N}), 1446\left(\mathrm{NO}_{2}\right.$ streching)

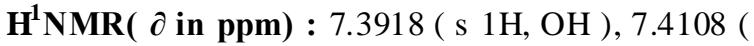
s, $1 \mathrm{H} \mathrm{Ar}-\mathrm{H}$ ), 7.5178 (d 1H Ar H), 7.6632 (d 1H Ar H) $6.6820(\mathrm{~s}, 1 \mathrm{H} \mathrm{Ar}-\mathrm{H})$

\section{Compound 3b:}

2-hydroxy-4-n itro[(2-n itrophenyl) diazenyl] phenol IR $\left(\mathbf{c m}^{-1}\right): 3486(v-\mathrm{OH}), 3377(v-\mathrm{OH}), 3083(v \mathrm{C}-$ $\mathrm{H}$ of Ar), $15851611(v-\mathrm{N}=\mathrm{N}-), 1301(v \mathrm{C}-\mathrm{N}), 1524$ $(v \mathrm{C}=\mathrm{C}), 1504,1345\left(v \mathrm{NO}_{2}\right)$ 
$\mathbf{H}^{\mathbf{1}} \mathbf{N M R}(\boldsymbol{\partial}$ in ppm) : 8.2012 (s $1 \mathrm{H}$ of phenolic $\mathrm{OH})$ , 8.1488 ( d 1 H of Ar H), 7.6150 ( d 1 H of Ar H), 7.2622 ( t 1H Ar H), 7.0088 ( t 1 H Ar H)

\section{Compound 3c:}

2-hydro xy-4-n itro (p-tolyl phenyl diazenyl) phenol

IR $\left(\mathbf{c m}^{-\mathbf{1}}\right)$ : 3431(v OH), 3027 ( $v$ C-Hof Ar), 1605 ( $v$ $\mathrm{N}=\mathrm{N}), 1268(v \mathrm{C}-\mathrm{N}), 1513(v \mathrm{C}=\mathrm{C}), 2919\left(v \mathrm{CH}_{3}\right)$, $1449\left(v \mathrm{NO}_{2}\right)$

$\mathbf{H}^{\mathbf{1}} \mathbf{N M R}(\partial$ in ppm) : 7.6371 (s $1 \mathrm{H}$ of $\mathrm{OH}), 7.4630$ ( d 1H of Ar H), 7.2952( d 1H of Ar H), 7.2004 ( d 1H of $\mathrm{Ar} \mathrm{H}$ ), 7.0630 ( d 1H of Ar H), 7.9660 ( d 1H of $\mathrm{CH}), 6.9217$ ( $\mathrm{s} \mathrm{H}$ of $\mathrm{CH}_{3}$ )

\section{Compound 3d}

2-hydro xy-4-nitro(naphthalene-1yl-phenyl diazenyl) phenol

IR $\left(\mathbf{c m}^{-1}\right): 3380(v \mathrm{OH}), 3230(v \mathrm{OH}), 1619(v-\mathrm{N}=\mathrm{N}-$ ), (v-C-N-), 1574 ( $v \quad \mathrm{C}=\mathrm{C}$ of $\mathrm{Ar}), 3048(v \quad \mathrm{C}-\mathrm{H}$ aromatic), $1460\left(v \mathrm{NO}_{2}\right)$

$\mathbf{H}^{\mathbf{1}} \mathbf{N M R}(\partial$ in ppm) : 9.0361 (s Phenolic-OH), 8.2661 ( $\mathrm{t} 1 \mathrm{H}$ of unsy $\mathrm{CH}$ ), 7.8315 ( t $1 \mathrm{H}$ of $\mathrm{CH}$ ), 8.3551 ( d1 H of $\mathrm{CH}), 7.7337$ ( d1H of $\mathrm{CH}$ ), 7.6809 ( $\mathrm{d} 1 \mathrm{H}$ of $\mathrm{CH}$ ), 7.5501 ( $\mathrm{d} 1 \mathrm{H}$ of $\mathrm{CH}), 7.1816,7.9140$ (s $1 \mathrm{H}$ of $\mathrm{CH})$

\section{Compound 3e}

2-hydro xy-4-n itro[(3-nitrophenyl) diazenyl] phenol

IR $\left(\mathbf{c m}^{-1}\right): 3386(v \mathrm{OH}), 3282(v \mathrm{OH}), 1587(v$ $\mathrm{N}=\mathrm{N}),(v \mathrm{C}-\mathrm{N}), 1417(v \mathrm{C}=\mathrm{C}), 1526\left(v \mathrm{NO}_{2}\right), 3087(v$ $\mathrm{C}-\mathrm{H}$ aro matic)

$\mathbf{H}^{\mathbf{1}} \mathbf{N M R}(\boldsymbol{\partial}$ in ppm) : 8.6629 ( $\mathrm{s} \mathrm{H}$ of $\mathrm{OH}), 7.2649$ ( $\mathrm{s} 1 \mathrm{H}$ of $\mathrm{SO}_{3} \mathrm{H}$ ), 8.0684 ( $\mathrm{s} \mathrm{H}$ of $\mathrm{CH}$ ), 7.3046 ( $\mathrm{s} \mathrm{H}$ of $\mathrm{CH}), 8.1529(\mathrm{~d} \mathrm{H}$ of $\mathrm{CH}), 8.1113(\mathrm{~d} \mathrm{H}$ of $\mathrm{CH})$, 7.1741 ( $\mathrm{t} \mathrm{H}$ of $\mathrm{CH}$ )

\section{Compound $3 \mathbf{f}$}

2-hydro xy-4-n itro-4-a mino-[(1,1'-biphenyl)-4-yldiazenyl] phenol

IR $\left(\mathbf{c m}^{-1}\right)$ : 3415, 3379 ( $v$ phenolic -OH), 3083 ( $v$ C$\mathrm{H}$ aromatic), 1579 ( $v \mathrm{C}=\mathrm{C}$ of $\mathrm{Ar}),(v \mathrm{C}-\mathrm{N}), 1595$ ( $v$ $\mathrm{N}=\mathrm{N}), 1490\left(v \mathrm{NO}_{2}\right),\left(v \mathrm{NH}_{2}\right)$

H$^{1}$ NMR ( $\partial$ in ppm) : 8.0278, 8.0066 ( $\mathrm{s}$ of $\left.\mathrm{OH}\right)$, 7.5476-7.3018 ( d H of CH), 7.2205 (s H, 3.38590), 6.1133 (s H of Ar ), $2.5100\left(\mathrm{~s} 1 \mathrm{H} \mathrm{NH}_{2}\right)$

\section{Compound 3g:}

4-((2-hydroxy-4-nitrophenyl) diazenyl) benzene sulphonic acid.
IR $\left(\mathbf{c m}^{-1}\right): 3411,3466(v \mathrm{OH}), 1528(v \mathrm{~N}=\mathrm{N}), 1(v$ C-N), 1619 ( $v \mathrm{C}=\mathrm{C}), 1350$ ( $v \mathrm{C}-\mathrm{H}$ aromatic $), 1465$ (v NO2) $1130,1188\left(v \mathrm{SO}_{3} \mathrm{H}\right)$

H$^{1}$ NMR( $\partial$ in ppm) : 8.5002 ( $\mathrm{s}$ of $\left.\mathrm{OH}\right), 8.1118(\mathrm{~s}$ of $\mathrm{OH}), 7.6321$ ( s $1 \mathrm{H}$ of $\mathrm{CH}), 7.7419$ (s $1 \mathrm{H} \mathrm{CH})$, 7.9799-7.3806 (d 1H Ar-H) 4.3859( s $1 \mathrm{H}$ of $\mathrm{SO}_{3} \mathrm{H}$ )

\section{Compound 3h}

5-((2-hydro xy-4-n itrophenol) diazenyl) ben zoic acid IR $\left(\mathbf{c m}^{-1}\right)$ : 3416, $3709(v \mathrm{OH}), 1604(v \mathrm{~N}=\mathrm{N}), 1(v$ $\mathrm{C}-\mathrm{N}), 1493(v \mathrm{C}=\mathrm{C}$ of $\mathrm{Ar}), 1709$ ( $v \mathrm{C}-\mathrm{H}$ of $\mathrm{Ar})$, $1527(v \mathrm{NO} 2) 1668(v \mathrm{COOH})$

$\mathbf{H}^{1}$ NMR( $\partial$ in ppm) : $12.7474(\mathrm{~s} 1 \mathrm{H}$ of $\mathrm{OH})$, 8.1783 ( s $1 \mathrm{H}$ of $\mathrm{OH}), 7.8062(\mathrm{~s} 1 \mathrm{H}$ of $\mathrm{COOH})$, 7.6765-7.4065 ( d 4H Ar ), 7.0924,7.4805( s H of Ar)

\section{Antimicrobial Activity:}

The compounds $3 a-3 h$ were screened for the antimicrobial study against four pathogens viz. Escherichia Coli, Staphylococcus aureus, pseudomonas aeroginosa and salmonella typhi by disc diffusion method. The compounds were dissolved in ethanol to form solutions. Sterile discs were dipped in solutions, dried and placed on nutrient agar plates inoculated with the above mentioned bacteria. The plates were incubated for 24 hours and the zone of inhibition was measured and listed below:

\begin{tabular}{|c|c|c|c|c|c|c|c|c|c|}
\hline & \multicolumn{7}{|c|}{$\begin{array}{c}\text { Sr. } \\
\text { no. }\end{array}$} & Pathogens & \multicolumn{7}{|c|}{ Zone inhibition in mm } \\
\hline 1 & S Typhi & 6 & NI & NI & NI & 10 & NI & 11 & NI \\
\hline 2 & E. coli & 10 & 7 & 4 & NI & 4 & 7 & 5 & NI \\
\hline 3 & S aureus & 19 & NI & NI & 8 & NI & 5 & NI & 14 \\
\hline 4 & P & 20 & 4 & NI & NI & 12 & NI & NI & 15 \\
\hline
\end{tabular}

Table: Antimic robial activity of azo co mpou mds (3a-3h) by disc diffusion method. 


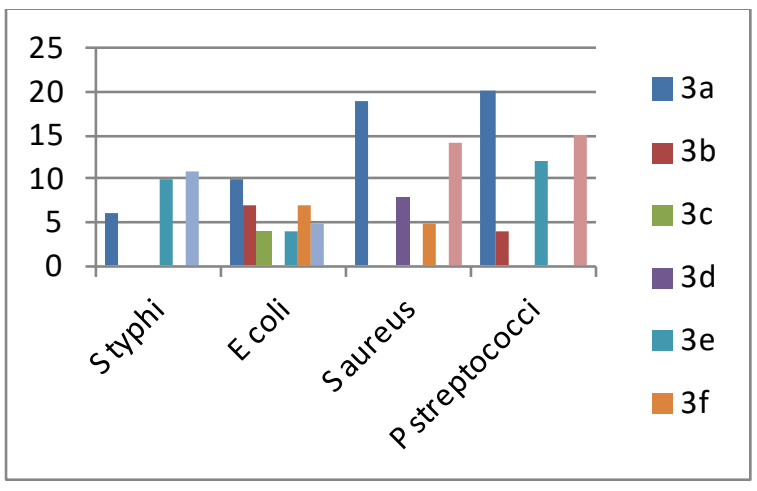

Fig: Antimicrobial activity of azo dyes against four pathogens

\section{Discussions-}

In the present study $3 \mathrm{a}-3 \mathrm{~h}$ azo dyes synthesized from di-substituted phenolic moiety i.e. 4-nitro catechol by diazotizing with eight different substituted aromatic amines. All synthesized products were gives significant yield and different range of colours. The IR spectra of synthesized compounds showed the absorption bands at 3200$3800 \mathrm{~cm}^{-1}$ and $1500-1620 \mathrm{~cm}^{-1}$ for phenolic $-\mathrm{OH}$ and azo group respectively. Also the absorption band for $\mathrm{C}=\mathrm{C}$ at $1490-1620 \mathrm{~cm}^{-1}$, aromatic $\mathrm{C}-\mathrm{H}$ is at 2915 $\mathrm{cm}^{-1}, \mathrm{NO}_{2}$ is at $1523 \mathrm{~cm}^{-1}$. Furthermore, the ${ }^{1} \mathrm{H}-\mathrm{NMR}$ spectrum shows peak for $-\mathrm{OH}$ proton is at 27.0811 $12.500 \mathrm{ppm}$.

The products were screened for antibacterial study against four pathogens possess moderate to good biological activity. The compound $3 \mathrm{a}$ showed excellent antibacterial activity against all pathogens. Whereas 3b, 3c, 3e, $3 \mathrm{f}$ and $3 \mathrm{~g}$ compounds show good biological activity against $\mathrm{E}$. coli and $3 \mathrm{a}, 3 \mathrm{e}$ and $3 \mathrm{~h}$ showed good antimicrobial activity against $\mathrm{S}$ typhi pathogen.

\section{Conclusion-}

The present work involves the synthesis of series of azo dyes from 1,2-dihydroxy-4-nitrobenzene to explore antimicrobial activity. All azo dyes were synthesized successfully and structurally interpreted by FT-IR, ${ }^{1} \mathrm{H}-\mathrm{NMR}$ and Mass spectroscopy. Compound $3 \mathrm{a}$ exhibits good antimicrobial activity against all pathogens viz. Escherichia Coli, Staphylococcus aureus, pseudomonas aeroginosa and salmonella typhi.

\section{References:}

[1] D, B. S., \& Thakare, N. S., Synthesis, spectral characterization and antimicrobial activity of some azo dyes derived from $\mathrm{p}$ - cresol. International Journal of pure and applied research in engineering and technology, 6(2), 510-516., (2017)

[2] D, B. S., Thakare, N. S., \& Ingole, S. D.. Synthesis and spectral analysis of some new phenolic azo dyes. International Journal of Chemtech Research, 10(9), 160-163, (2017)

[3] J., J. A., Kadhim, S. S., Mahmood, M. A., \& Obaid, S. M. Synthesis, spectral studies and biological activity of azo dye complexes with some metallons. Journal of Global Pharma Technology, 10(6), 97-106, (2018).

[4] M., M. N., \& Keshavayya, J.. Synthesis, spectroscopic characterization and pharmacological studies on novel sulfamethaxazole based azo dyes. Journal of King Saud University- SCIENCE, 1-9, (2018)

[5] M., R. K., \& Thakare, N. S.. Synthesis and antimicrobial activity of azo compounds containing m-cresol moiety. Chemical Science Transactions, 2(1), 25-28, (2013)

[6] Patni, N. P.. Diazotization and coupling reactions of differently substituted aromatic amines and investigation of their salvatochromic behaviour. Der Chemica Sinica, 7(2), 93-100, (2016)

[7] Pranab, D., \& Begum, J. Synthesis of mordant azo dyes using supported diazonium ions and Bronsted acidic ionic liquids. Indian Journal of Chemistry, 57B, 355-361, (2018).

[8] S, S. N., \& Thakare, N. S. A mino phenolic AZO compounds synthesis and biological analysis. Research Journal of chemical sciences, 6(8), 36-42., (2016)

[9] S., K. S., \& Thakare, N. S.. Synthesis and spectral characterization of some azo amine dyes. Journal of Global Biosciences, 5(1), 3615-3617., (2016)

[10] T., K. K., Keshavayya, J., \& Rajesh.. Synthesis, Spectral Characterization and Biological study of Heterocyclic Azo dyes. International journal of engineering technology science and research, 4(11), 996-1000, (2017). 